\title{
Distribution of the termite Reticulitermes lucifugus (Isoptera) and the specifics of its invasion in Ukraine
}

\author{
Igor R. Merzlikin
}

Sumy State Pedagogical University (Sumy, Ukraine)

\begin{abstract}
Distribution of the termite Reticulitermes lucifugus (Isoptera) and the specifics of its invasion in Ukraine. - I. R. Merzlikin. - The only known termite species occurring in Ukraine is the Mediterranean termite Reticulitermes lucifugus Rossi, 1792 (Rhinotermitidae). The description of currently known finds of this species in six administrative regions of Ukraine is given in this article along with a generalised map of distribution. At the present time, the species occurs in islet forests and artificial pine plantations of the Lover Dnipro region and also in ravines and roadsides. Termite infection threats to buildings in Ukraine is very real and in recent years has become more common. This article presents the development of the species' invasion from the Black Sea area (from Odesa and Mykolaiv) to the north-east direction through Zaporizhia and Dnipro cities. Four finds of termite settlement in north-east Ukraine are described — in Sumy city (three cases) and Hlybne village, Krasnopillya Raion, Sumy Oblast (one case). The first place of the species' discovery in this area was in Hlybne in summer 2013, when in a private home tables, the cupboard and commode were affected by termites. In this summer, the residents of the house moved here to live from Bashkortostan, Russia. Over time, all the furniture became unusable and was thrown away. The species of termites in those furniture remained unclear. Another record locality was a flat in Sumy city on the eighth floor of a 12-storey building, where on 15 of July 2015 termites and their nesting chambers were found behind a wall mirror, which was bought in a supermarket by its owner 9 months before. The insects were also found on adjoining floors above. The termites were next discovered in late April 2016 in a private home in a woodbased wall mirror that was purchased in the same supermarket. The fourth termite find was reported from a flat in a 9-storey building. Its owner purchased a large wall mirror in the same supermarket. The wooden base of the mirror was struck by termites. All records of termites were located in different parts of the city. These new finds expand the boundaries of the species' distribution in Ukraine by $270 \mathrm{~km}$ to the north.
\end{abstract}

Key words: termites, Reticulitermes lucifugus, expansion, invasive species, Ukraine

\section{Introduction}

Due to the world globalization in recent decades, trade flows between different countries and within them significantly increased. That is why the problem of control and preventing the penetration of alien pest species into new territories becomes rather acute. Different wood destroyers, including termites, are a considerable problem for people. The interest to termites sharply increased due to the expansion of trade relations among many countries, especially where termites cause tangible losses. Experts consider that in the USA alone economic losses from the activity of a single species of termites - the Formosan subterranean termite Coptotermes formosanus Shireki, 1909 are up to $\$ 1$ bln per year (Termite..., 2014). Global damage from termite activity is estimated at $\$ 3$ bln per year (Anderson, 2005). It is very topical not only for the "hot" countries, but also for countries of temperate climate, when termites can be transferred to with imported goods. The more so that the world termite population is increasing. This rise is accompanied with the adaptation of these insects to colder and drier conditions of existence (Sapunov, 2008, 2009). As a result, Reticulitermes termites have been already found in Canada (Grace, 1989; Scaduto et al., 2012) and England, Devon County (Verkerk \& Bravery, 2001).

Therefore, it is very important to monitor this situation and not to miss the first cases of invasive species occurrence with the aim of taking measures, preventing its consolidation on a new territory and further dispersal in time. The purpose of this work is to analyse the spread of termites in the territory of Ukraine and their appearance in new areas.

Correspondence to: I. R. Merzlikin; Sumy State Pedagogical University, Romenska St. 87, Sumy, 40002 Ukraine: e-mail: mirdaodzi@gmail.com; orcid: 0000-0001-8209-9144 


\section{Material and methods}

The review of distribution of termites in Ukraine is mainly based on the publication by M. V. Beliajeva and D. V. Zhuzhikov (1974) complimented by more recent studies (Barsov, 1988; Termites don't like ..., 1999; Tur \& Rusina, 2000; Tsvetkova et al., 2001; Tur, 2002, 2004; Beliajeva et al., 2005; What are termites ..., 2013). The results are demonstrated in Fig. 1 and Table 1.

As for the north-east of Ukraine, records of termites have not been reported before. Currently there are a number of cases when termites are transferred with wood and goods beyond their natural habitats (Scaduto et al., 2012). Therefore, since 2005, we have been polling citizens (especially students) whether they have encountered "small white insects" causing damage to wood or "white ants" as they call them in everyday life.

\section{Review of termite finds in Ukraine}

In Ukraine, termites were first found in the 1860s. F. P. Köppen (1880) first mentioned them based on the reports by I. M. Vilgalm and I. I. Mechnikov, who discovered Reticulitermes lucifugus Rossi, 1792 in Odesa quarantine harbour (Beliajeva \& Zhuzhikov, 1974). Later it was argued whether termites were of local origin or had been brought from other countries and acclimatized in that region. This issue has been discussed in the literature since the end of the last century.

For a long time this species was considered to be imported due to the anthropical area in residential and commercial buildings with agricultural fruit and vine crops (Beliajeva et al., 2005). F. P. Köppen supposed that $R$. lucifugus had been brought to Odesa port by foreign ships. N. G. Lignau (1915) considered that the species was not a random object in Ukraine but an element of the Mediterranean fauna. According to A.V. Bogachov (1941) and V. P. Tsvetkova (1962), R. lucifugus is a tertiary relict in Azerbaijan and Southern Ukraine. In Ukraine, R. lucifugus was studied by V. P. Tsvetkova (1950, 1953).

Later the Mediterranean termite was found in the wild and in areas not related to humans, e.g. in wooded ravines and steppe areas (Barsov, 1988; Tur \& Rusina, 2000; Tur, 2004; Beliajeva et al., 2005).

I. I. Puzanov (1960) in his faunal zonation of Steppe Ukraine indicates the presence of termites (Termes lucifugus) in the Lower Dniester region and along the Bug.

Field observations undertaken by N.V. Beliajeva and D.V. Zhuzhikov near Odesa, Kherson, Dnipropetrovsk (Ukraine) and Meghry Valley (Armenia), Barda (Azerbaijan) near Derbent (The Republic of Dagestan, The Federation of Russia) showed that termites inhabited mainly humid places, old stumps of walnut (Juglans regia), figs (Ficus carica), oak (Quercus sp.), locust (Robinia psevdoacacia), pear (Pyrus sp.), poplar (Populus sp.) and other trees. Sometimes these termites can be found under stones and on mountain slopes - in the roots of sagebrush and other shrubs in relatively dry areas (Megry, Derbent). The results of observations convinced these authors that termites were aborigine inhabitants of forest rests in ravines (Ukraine) and on the slopes of mountains (Caucasus). V. A. Lozinsky also had such point of view. He considered that the main biotopes of termites in southern Ukraine were the slopes of combes and other plots of land unsuitable for economic use, where - as he said - termites migrated to various buildings, gardens and vineyards (Beliajeva \& Zhuzhikov, 1974; Zhuzhikov, 1979).

Analysing all places of finding of R. lucifugus in the territory of the former USSR and particularly in Ukraine, N.V. Beliajeva and D.P. Zhuzhikov (1974) concluded that the south of Ukraine, Megry valley, Barda, Derbent were the eastern part of this termite's range, which stretches to the Kopet Dagh mountains in the east (Turkmenistan) and to Dnipropetrovsk in the north (Beliajeva \& Zhuzhikov, 1974).

Nowadays, $R$. lucifugus was discovered in islet forests of Lower Dnipro sands as a part of steppe communities with the dominance of sagebrush Artemisia marschalliana where it has positive meaning in the distraction of wood in natural biocoenoses and in particular on Ivano-Rybalchansky and Solenoozerny sites of the Black Sea Reserve (Tur, 2000, 2002, 2003; Tur \& Rusina, 2005; Shevtsova et al., 2001; Beliajeva et al., 2005). 
In the forest islets, nests of this species are wet fallen trunks and branches of birch Betula borysthenica and oak Quercus robar. The R. lucifugus family consists of some thousands of individuals. In the steppe area, it is found more seldom. There R. lucifugus nests are located at the base of the shrub of sagebrush A. marshal and salsify Tragopogon dolichocarpus. Their population is rather small and includes up to 60 insects in each. This species is widely met in artificial pine plantations of Kherson Oblast. The density of the nests there was 100 nests per $1 \mathrm{~km}^{2}$. It is also found in ravines and roadsides (Lozinsky, 1962; Tur \& Rusina, 2001).

By now, $R$. lucifugus had formed sustainable population in the south of Ukraine and it disperses further to north. In particular nowadays the species findings are described in 6 administrative regions, including the infection with these termites buildings in Kherson (Malko, 1934; Tur \& Rusina, 2000), Mykolaiv (Churikova, 1968; Shevtsova, 1939), Odesa (Lignau, 1915; Nikitin, 1927; Lozinsky, 1962); Zaporizhia (Topchiev, 1953; What are termites ..., 2013), Dnipropetrovsk (Akimov, 1940; Barsov, 1988) Oblasts and in Sumy (our data).

Based on this data the previous northern border of the species' distribution in Ukraine stretched to Dnipropetrovsk (Beliajeva \& Zhuzhikov, 1974; Beliajeva, 2004). The distribution of species records is shown in Fig. 1 and listed in Table 1.

The numbers on the map indicate the area of termite findings in the regions as shown in Table 1. As we can see, it occurs in settlements located mainly in the area of large sea and river ports and extends up to the banks of the Dnipro and its reservoirs.

Because of the long-lasting debate concerning the species diagnosis of European representatives of Reticulitermes, some experts had no full confidence in a correct identification of the termites recorded in the south of Ukraine and in the Caucasus (Beliajeva \& Zhuzhikov, 1974, 1979; Shteinberg, 1962). Now, in Europe 6 phenotypes of the species are known: R. santonensis in the west of France; R. grassei in the south-west of France, in the north-west and in the south of Spain and Portugal; R. banyulensis in the north-east of Spain, in the central part of the Iberian Peninsula and in the south-west of France; $R$. lucifugus in Italy and in the south-east of France; $R$. balkanensis in the Balkans; $R$. balkanensis in the north of Italy and south-east of France (Clement et al., 2001). Another form, R. clypeatus Lash, 1952 occurs in Turkey, Iraq and perhaps in Iran, as well as in Romania (Beliajeva \& Zhuzhikov, 1974).

Thus, at least two species of Reticulitermes - R. lucifuges and R. clypeatus - can be found at the boundaries of the former USSR. The importation of $R$. flavipes is impossible, since it had already occurred in Hamburg for several decades before it was revealed in Ukraine (Beliajeva \& Zhuzhikov, 1974).

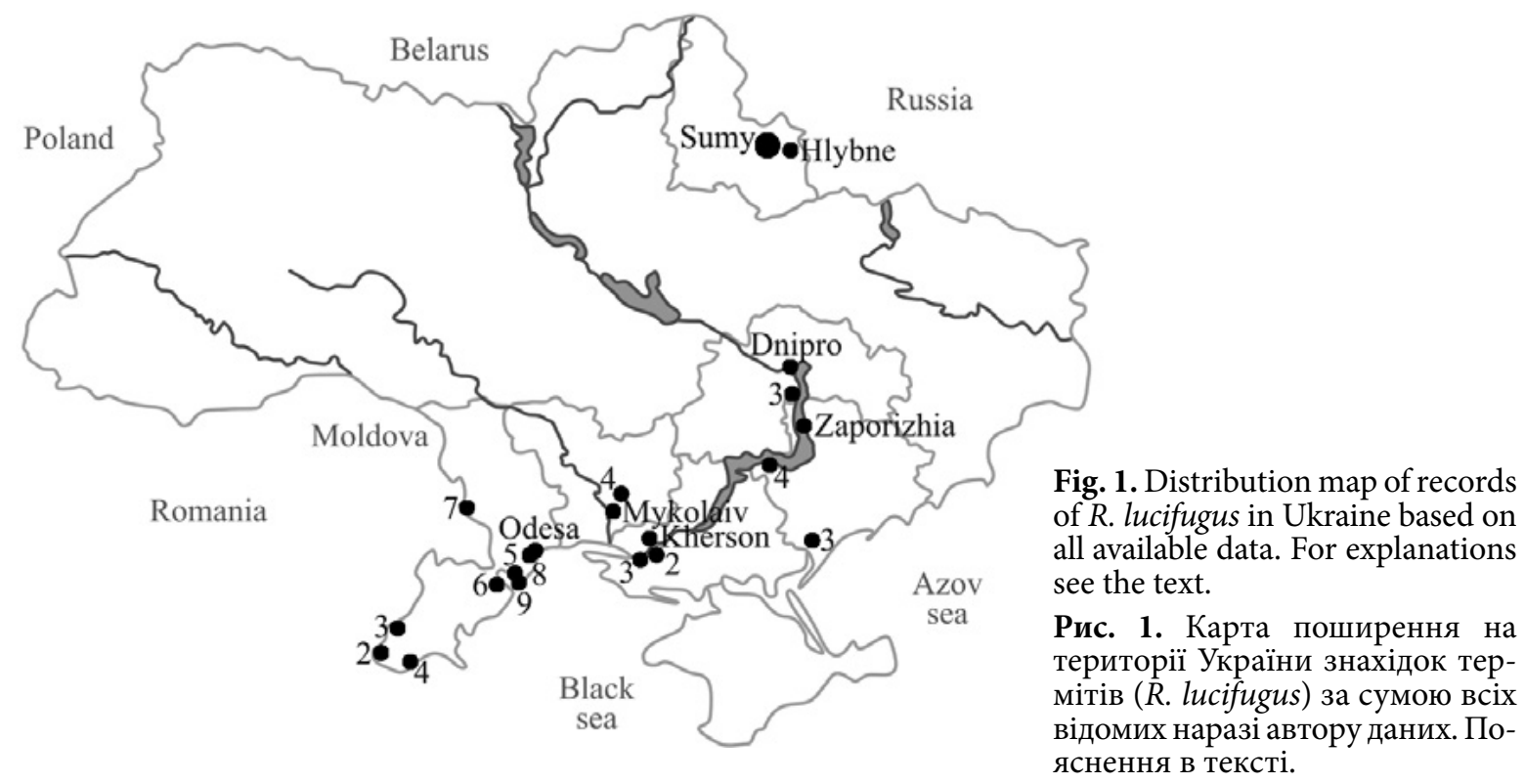


Table 1. Occurrence and records of termites in the territory of Ukraine (according to N. V. Beliajeva \& D. P. Zhuzhikov, 1974, with changes and additions)

Таблиия 1. Місця мешкання і збору термітів на території України (за: Н. В. Беляева, Д. П. Жужиков, 1974, із змінами та доповненням)

\begin{tabular}{|c|c|c|}
\hline Oblast & Record locality and date & Source \\
\hline Odesa & $\begin{array}{l}\text { 1) west of Izmail Raion (1887), 2) Reni (1883), 3) Bol- } \\
\text { grad (1887), 4) Izmail (1893, 1968, 1973), 5) Babel } \\
(1870), 6) \text { Bilgorod-Dnistrovsky }(1911), 7) \text { Purkary } \\
(1887), 8) \text { Ovidiopol, 9) Bugaz }(1910), 10) \text { Odesa and } \\
\text { its Suburbs (1860-1864, 1893, 1908, 1914, 1932, 1937, } \\
\text { 1958, 1964-1973) }\end{array}$ & $\begin{array}{l}\text { Rekalo, 1889; Vidgalm, 1886; Yakobson, 1904; } \\
\text { Mokrzhecky, 1903; Stuart, 1889; Malko, 1934, 1957; } \\
\text { Lozinsky, 1958, 1962; Tsvetkova, 1939, 1950, 1953, } \\
\text { 1962; Okolovich, 1888; Köppen, 1880, 1882; Na- } \\
\text { sonov, 1884; Chervinsky, 1901; Lignau, 1915; Niki- } \\
\text { tin, 1927; Churikova, 1968; Zhuzhikov, Korovkina, } \\
\text { 1968; Aksiutova et al., 1970 }\end{array}$ \\
\hline Mykolaiv & $\begin{array}{l}\text { 1) Mykolaiv (1934), 2) Sviato-Troitske (1957), } \\
\text { 3) Kysliakivka (1956), 4) Voskresenske (1956-1957) }\end{array}$ & $\begin{array}{l}\text { Malko, 1934, 1957; Tsvetkova, 1939, 1950, 1962; } \\
\text { Lozinsky, 1958, 1962; Churikova, } 1968\end{array}$ \\
\hline Kherson & $\begin{array}{l}\text { 1) Herson, 2) Oleshky (= Tsiurupynsk) 1937, 1938, } \\
\text { 1958), 3) Oleshky (= Tsiurupynsk) forestry (2000- } \\
\text { 2002), 4) Natural landmark Burkuty Oleshky (= } \\
\text { Tsiurupynsk) forestry }(2000-2002) \text {, 5) Hola Pristan } \\
(1958), 6) \text { Black Sea Biosphere Reserve }(2002-2005)\end{array}$ & $\begin{array}{l}\text { Malko, 1934, 1957; Tsvetkova, 1939, 1950, 1962; } \\
\text { Lozinsky, 1958, 1962; Churikova, 1968; Tur, 2000, } \\
\text { 2002, 2004; Tur, Rusina, 2001; Shevtsova et al., 2001; } \\
\text { Beliajeva et al., } 2005\end{array}$ \\
\hline Zaporizhia & $\begin{array}{l}\text { 1) Melitopol forestry (1956), 2) Zaporizhia (1997- } \\
\text { 1999), 3) Melitopol (1997-1999), 4) Kamianka-Dni- } \\
\text { provska (1997-1999), 5) Zaporizhia Raion (1997- } \\
\text { 1999), 6) Zaporizhia Oblast (1997-1999) }\end{array}$ & $\begin{array}{l}\text { Topchiev, 1953; Termites don't like ..., (1999); What } \\
\text { are termites..., (03.03.2013) }\end{array}$ \\
\hline Dnipro & $\begin{array}{l}\text { 1) Dnipro (= Dnipropetrovsk) (1931), } \\
\text { 2) near Dnipro (1979), } \\
\text { 3) near Voiskove Solone (1965), } \\
\text { 4) near Vojskovoje Solone (1973) }\end{array}$ & $\begin{array}{l}\text { Akimov, 1940; Beliajeva, Zhuzhikov, 1974; Barsov, } \\
1988\end{array}$ \\
\hline Sumy & $\begin{array}{l}\text { 1) Hlybne village (2013) } \\
\text { 2) Sumy }(2015,2016)\end{array}$ & Our data \\
\hline
\end{tabular}

Reticulitermes is common in regions with temperate climate. It can be found in the whole territory of the USA and it has also spread further north to Orlando and Manitoba provinces, Canada (Grace, 1989; Biologists ..., 2012). It was also found in Asia, North Africa, Southern Europe (Plateaux \& Clement, 1984; Grace, 1989), and south-west England (Verkerk \& Bravery, 2001).

Termites are dangerous not only for wooden buildings. If they penetrate into urban central heating systems, it will create a huge problem (Lainé, 2002). It is also very difficult to find these termites. Experts consider that nearly 30 years have passed since the appearance of termites in England before they had been found (Verkerk, 1998). The termite colony formation needs very small number of individuals and, theoretically, any group can form a viable colony (Lainé, 2002).

R. lucifugus demands the most careful attention in Ukraine since it can seriously harm human buildings (Vasiliev, 1987; Beliajeva, 2005). For living plants, this species is a secondary pest, but also in this capacity, it can greatly accelerate the death of vines, fruit and park density.

Termite infection threat to human buildings in Ukraine is very real and in recent years is becoming more actual. Thus, according to the Zaporizhia Regional Sanitary-Epidemiological Station, many houses in this area were damaged by termites. In Melitopol, termites were revealed in a huge number. As of $1999,60 \%$ of the city housing fund were infected by termites. Many buildings, especially in the old part of Zaporizhia, were in disrepair, particularly 17 houses in three streets in Zhovtnevy district of Zaporizhia were significantly damaged (Termites don't like ..., 1999).

\section{Description of the finds in Sumy and Sumy Oblast}

The first finds of termites in the north-east of Ukraine were revealed in Sumy city (three records) and in Hlybne village, Krasnopillia Raion, Sumy Oblast (one record).

The first place of the find was in Hlybne village (V. M. Natalukha, personal communication). In summer 2013, when he arrived to his relatives who lived in this village in one of the private homes, he learned from them that the tables, cupboard and the commode were affected by termites. At 
dusk, he observed milk-white insects. In summer, the residents of the house moved here to live from Bashkortostan, Russia. Later, all the furniture became unusable and was thrown away. The species identification of these termites remained unclear.

On the 31 of July 2015, the author was informed that termite-like insects were found in a 12-storey building in Sumy. As it turned out in mid-September 2014, the owner of the flat on the eighth floor bought a large mirror in a supermarket and attached it to the wall in one of the rooms. Nobody lived in that flat because it was under repair. In mid-July, he noticed that some dust had appeared behind the mirror. When he disconnected the mirror from the wall he saw some damage and numerous milky-white insects, the length of which was $2-3 \mathrm{~mm}$ (Fig. $2 a$ ).

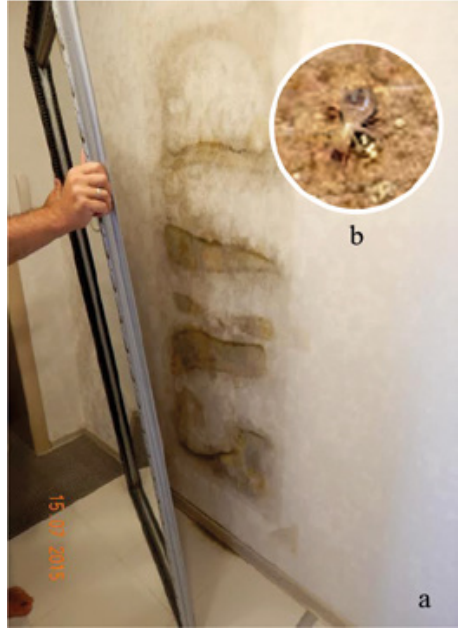

Fig. 2. Location of termites in the building in Sumy city: a) the wall behind the mirror with nest cells made by termites from damaged wood and faecal pellets; b) photo of the termite.

Рис. 2. Місцезнаходження терміта в житловому будинку м. Суми: а) стіна за дзеркалом iз гніздовими камерами, які збудували терміти з ушкодженої деревини і грудочок екскрементів; б) фотографія терміта.

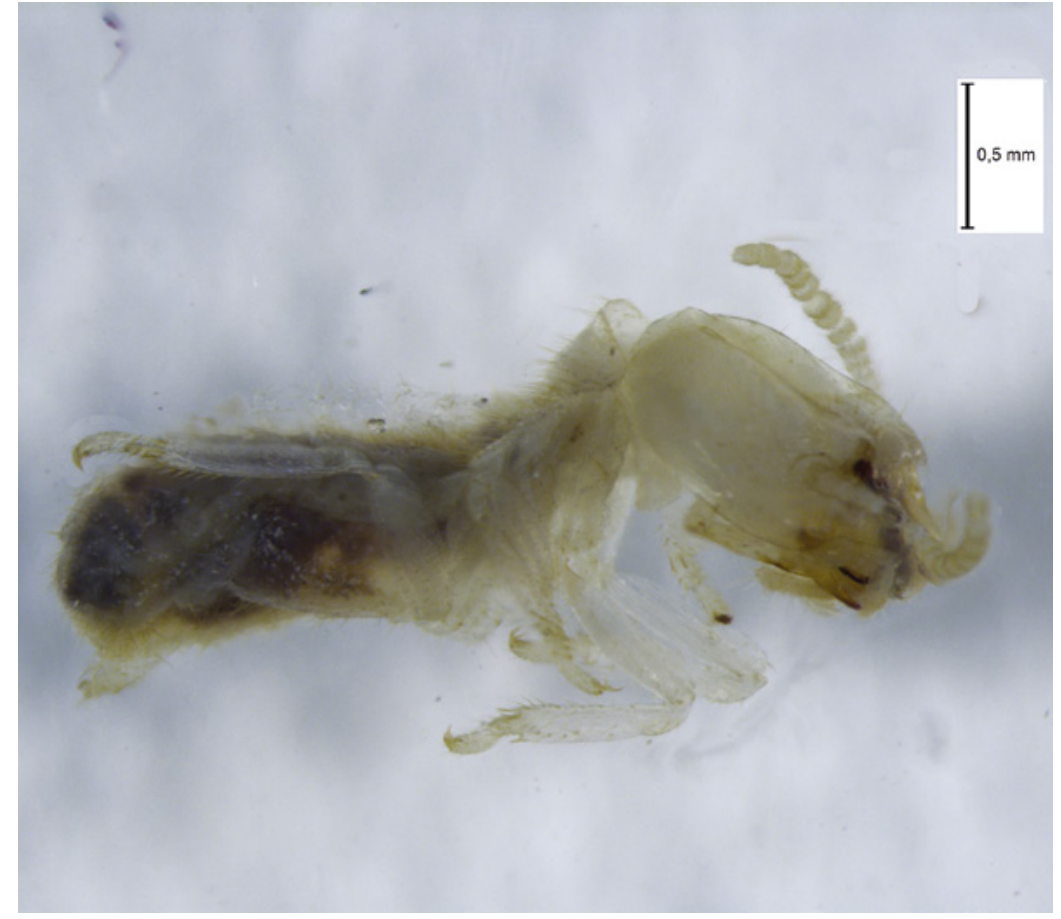

Fig. 3. The Mediterranean termite Reticulitermes lucifugus.

Рис. 3. Терміт світлобоязкий, Reticulitermes lucifugus.

Neighbours living on the ninth and tenth floors above this flat also began to complain that they had some "white small bugs". In both flats, those insects stayed near the ventilation holes in the kitchen at first, but then they began to appear throughout the whole flat. The tenants of those flats appealed to a private company for desinsection. According to the employees of that firm, it was the first case of finding termites in Sumy.

Most likely that mirror (which have been bought through one of the trade systems, delivering goods from different regions) itself was the source of insects appearance. Unfortunately, we could not learn where the mirror had been brought from as well as who had been its manufacturer. We also could not ascertain if there were more mirrors infected with termites. Unfortunately, we could not get any specimens of these insects. The conclusion that the insects were termites was drawn based of the nature of caused damage to the mirror frame and photos of insects collected from their holes in the mirror. 
Looking at various woods pests photos given by the author and the nature of damage (from different sources in Internet) the owner of the flat identified the insects as termites. The demonstration of a video of $R$. lucifugus from Odesa to him allowed to suggest that we should speak about this species of termites. The morphological material suitable for identification of the species was not retained. There is only a small-scale photo of the wall section with young specimens, but it is not enough for a morphological analysis (Fig. 2 b). It is known that in the south of Ukraine Reticulitermes lucifugus Rossi, 1792 occurs, which belongs to soil wooden termites (Rhintermitidae family). The author classifies this find as R. lucifugus.

The other finding of termites was also detected in Sumy. At the end of April 2016, a big mirror bought in the same supermarket was placed in a private house. Within some days, the master of the house entering the room where the explained mirror was and turning the light on saw about 10 "ants" crawling on it. He crushed the ants, pulled of the mirror, brought it in a storage and sprayed it with diclophos. After the smell disappeared, he hanged the mirror on its former place. Those insects did not appear there again.

One specimen of the termite was given to the author (Fig. 3). This termite was transferred to the National Museum of Natural History NAS of Ukraine (inventory number IKNDFZ-Iv256). The author identifies this find as R. lucifugus.

The fourth finding of termites was detected in Sumy in May 2016 (D. V. Pelekh, personal communication). In the same supermarket, a large mirror was bought and attached to the wall in a flat in a 9-storey building, after which the owner went on vacation. Returning home, he found that the entire base of the mirror was "corroded", and beneath there was a heap of rubble. The owner replaced the base of the mirror, and threw the old one into the garbage. The species affiliation of the termites could not be determined, but it can be assumed that it was the same species $-R$. lucifugus.

Each place of termite record were located in different parts of the city.

\section{Discussion}

Due to the intensity of the commodity circulation, a hypothetical problem of termites import becomes real. The possibility of termites taking roots in the territory of north-east Ukraine and specifically in Sumy region is increasing due to the significant rise in temperature warming, arid climate and sufficient food resources. There are friendly ecological conditions for the species and suitable habitats both in natural biotopes and in urban landscapes.

Similar cases has been already observed for other species. Thus, in the last decades, the mantis Mantis religiosa, which used to be a very rare insect there and to fly periodically to this area, turned into a common breeding representative of the entomofauna in Sumy Oblast. We began to find the locust Locusta migratoria on steppe sites more often. The nesting of the wheatear Oenanthe isabellina, which is typical for south-eastern steppes, is also observed in dry places (Knysh, 2001).

However, termite finds in populated areas of north-east Ukraine indicate that the synanthropic environment for them, as well as for many invasive species, is still the key habitat and corridor of expansion and is associated with wood, as it was pointed out by researchers earlier (Zagorodniuk, 2012; Evans et al., 2013).

\section{Conclusion}

The analysis of termite finds in Ukraine indicates the spread of termites to north-east from the Northern Black Sea Region. Cases of termites finding in Sumy is an example of possible species infiltration into a new area with various goods and taking roots in that territory under favourable circumstances. These new founds expand the boundaries of distribution this species in Ukraine by 270 $\mathrm{km}$ to the north.

\section{Acknowledgements}

The author sincerely thanks I. Zagorodniuk for his advice and valuable comments, and D. V. Pelech and V. M. Natalukha for providing additional information. 


\section{References}

Akimov, M. O. 1940. About finds of termites Reticulitermes lucifugus Rossi in Dnipropetrovsk. The digest of works of the Biological faculty of Dnipropetrovsk State University, 3: 9-11. (In Russian)

Aksiutova, L. N., D. P. Zhuzhikov, E. X. Zolotariov. 1970. Eating the wood of different trees by Reticulitermes Lucifugus Rossi. Vestnik of the Moscow University, Biology, Agrology, 4: 105-106. (In Russian)

Anderson, A. 2005. Termites of North Australia. CPC, Alice Spring, 1-84.

Barsov, V. A. 1988. Reticulitermes lucifugus Rossi in Dnipropetrovsk region. Vestnik zoologii, 22 (5): 23. (In Russian)

Beliajeva, N. 2004. Termites of Russia and adjacent territories (within the borders of former USSR). Rat-inform, 3: 32-35. (In Russian)

Beliajeva, N. 2005. Termites damaging activities (report 3). Rat-inform, 1: 17-20. (In Russian)

Beliajeva, N. V., D. P. Zhuzhikov. 1974. Materials about the fauna and termites distribution in the USSR. Works of entomol. sector of problem. Research lab. on the Development of Methods of Fight with Biological Material Damage. Biological Faculty of Moscow University, 5 (Termites): 7-61. (In Russian)

Beliajeva N. V., L. G. Rusina, Z. V. Seliunina, I. G. Dovgobrod, A. V. Rasskazova. 2005. The perspectives of studying some peculiarities of common European termite biology and ecology of the Black Sea Biosphere Reserve. Faltsfein reading: Digest of Scientific works: in 2 volumes. Volume 1. Kherson State University, Natural History Institute, 58-59. (In Russian)

Bogachov, A. V. 1941. Termites distribution in Azerbaijan SSR. News of the Academy of Science of AzSSR, 1: 81-83. (In Russian)

Chervinsky, K. K. 1901. The list of termites and their description. The Collections of the Zoology Class of the Imperial University of Warsaw, 7: 1-3. (In Russian)

Churikova E. K. 1968. The buildings damaged by termites in Nikolayev region, UkrSSR. Termites and measures to fight them. Ylym, Ashgabat, 152-155. (In Russian)

Clément, J.-L., A.-G. Bagnères, P. Uva, et al. 2001. Biosystematics of Reticulitermes termites in Europe: morphological, chemical and molecular. Insectes Sociaux, 48 (3): 202-215.

Evans, Th. A., B. T. Forschler, J. K. Grace. 2013. Biology of Invasive Termites: A Worldwide Review. Annual Review of Entomology, 58: 455-474.

Grace, J. K. 1989. Northern subterranean termites. Pest Management, 8: 14-16.

Knysh, N. P. 2001. Notes about rare and little-known birds of forest-steppe zone of Sumy region. Berkut, 10: 1-19. (In Russian)

Köppen, F. P. 1882. Insect pests. Orthopterans, Beetles and Hymenoptera, 2. Sankt-Petersburg, 1-583. (In Russian)

Lainé, L. V. 2002. Biological Studies on two European Termite Species: Establishment Risk in the UK. A thesis submitted for the degree of Doctor of Philosophy of the University of London, 1-164.

Lignau, N. G. 1915. Our termites. School Excursions and a School Museum. Odessa, 3: 19-24. (In Russian)

Lozinsky, V. A. 1958. Termites in the South of Ukraine. Visnyk of Agricultural sciences, 1: 89-91. (In Ukraine)

Lozinsky, V. A. 1962. Termites of Ukraine-wood and plants pests. Termites and measures to deal with them. Publishing outfit of the Academy of sciences, TSSR, Ashgabat, 84-87. (In Russian)

Malko, B. D. 1934. Termites - the plaque of wood. Protect the harvest, 1: 34-35. (In Russian)

Malko, V. D. 1957. Termites in Ukraine and fight against them. Gosstrojizdat UkrSSR, Kyiv, 1-12. (In Russian)

Mokrzhecky, S. A. 1903. The List of Insects and Other Invertebrates, Which Were Found on a Vine grapevine in European Russia and on the Caucasus. Saint-Petersburg, 1-12. (In Russian)

Nasonov, N. V. 1884. The list and description of the collection of insects biology. The Collection of the Biology Class of the Imperial University of Warsaw, 2: 1-64. (In Russian)

Nikitin, S. A. 1927. About termites from vicinities of Odessa. The Notes of Odessa Society of Naturalists, 43: 56-59. (In Russian)

Okolovich, O. 1888. The report on the inspection of vineyards in Akkerman and Izmail districts of Bessarabia province in 1886-1887. The Report of Odessa Philoksera Commission for the Period of 1886 and 1887. Odessa, 133-143. (In Russian)

Puzanov, I. I. 1960. Faunistic zoning of Steppe Ukraine, Odessa. Science Yearbook. Odessa State University, Department of biology. Odessa, 2: 100-103. (In Russian)

Rekalo, E. O. 1889. About insects pests of Bessarabia in 1987. Works of the VIIIth Regional Congress of Entomologists in Odessa in 1888, 6: 18-21. (In Russian)

Sapunov, V. B. 2008. Global dynamics of termite population: modeling, control and role in green house effect. Proc. $6^{\text {th }}$ Int Conf. Urban Pests. Budapest, 389-393.

Sapunov, V. B. 2009. Populating dynamic of termites and their metabolism. Biosphere: Interdisciplinary Journal of Applied Science. The found of scientific research of XXI century, Sankt-Petersburg, 2: 257-263. http://goo. $\mathrm{gl} / \mathrm{e} 3 \mathrm{HPaB}$ (In Russian)

Scaduto, D. A., R. G. Shawn, L. L. Emma, G. J. Thompson. 2012. Genetic Evidence for Multiple Invasions of the Eastern Subterranean Termite Into Canada. Molecular ecology and evolution, 41 (6): 1680-1686.

Shevtsova, O.N., L.P. Tur, L.Y. Rusina. 2001. About joint ants settlements and Reticulitermes lucifugus Rossi in Kherson region. Modern Ecology Problems of Ukrainian Polesie Region and Contiguous Territories (to 
the $15^{\text {th }}$ anniversary of the accident at the Chernobyl N.P.S.). Materials of the International Scientific and Practical Conference. Nizhyn, 128-129. (In Russian)

Shteinberg, D. M. 1962. Termites of the SSSR and the level of their scrutiny. Termites and measures to fight them. Ylym, Ashgabat, 11-16. (In Russian)

Stuart, A. F. 1889. The minute of the second meeting of representatives of district councils of southern provinces. Works of the VIIIth Regional Congress of Entomologists in Odessa in 1888, 1: 21-33. (In Russian)

Termites don't like «heat treatment». 1999. Newspaper «Segodnja», 50 (305), 18.03.1999. http://goo.gl/lUNlxa (In Russian)

Termite Facts and Figures. LSUAgCenter.com. Innovate, Educate, Improve lives. 9/22/2014. http://goo.gl/Z6eJw4

Topchiev, A. G. 1953. Animal population on the soil of artificial forests plantations in Altagir and Rodionov countries. Scientific Notes of Dnipropetrovsk State University, 38: 93. (In Russian)

Tsvetkova, V. P. 1939. Termites of the South of Ukraine. Works of Odesa Agricultural Institute, 1: 63-75. (In Ukraine)

Tsvetkova, V. P. 1950. Fight against termites in buildings. Priroda, 1: 95-96. (In Russian)

Tsvetkova, V. P. 1953. About Reticulitermes lucifugus Rossi biology. Entomol. Obozrenie, 33: 132-141. (In Russian)

Tsvetkova, V. P. 1962. Termites Reticulitermes lucifugus Rossi in the South of Ukraine. Termites and measures to fight them. Ylym, Ashgabat, 28-36. (In Russian)

Tur, L. P. 2000. Life cycle of Reticulitermes lucifugus Rossi (Isoptera: Rhinotermitidae) in Kherson region. Method: Science work collection. Issue «Millenium». Kherson, 46-47. (In Russian)

Tur, L. P. 2002 (2003). The precopulative behavior of Reticulitermes lucifugus (Isoptera: Rhinotermitidae) in the South of Ukraine (Kherson region). Izvestija of Kharkov Entomological Society, 1-2: 119-121. (In Russian)

Tur L. P. 2004 a.The colony structure and fenology of Reticulitermes lucifugus (Isoptera: Rhinotermitidae) in artificial pine forest of Kherson region. Vestnik zoologii, 38 (2): 81-86. (In Russian)

Tur, L. P. 2004 6. Reticulitermes lucifugus settlements (Isoptera: Rhinotermitidae) on the steppe places of Black Sea biosphere reserve. Vestnik zoologii, 38 (5): 85-89. (In Russian)

Tur, L. P., L. Y. Rusina, 2000a. Reticulitermes lucifugus Rossi life cycle and family structure (Isoptera: Rhinotermitidae) in pine plantations of Kherson region. Naukovij Visnik of Uman State Pedagogical University. Series Biology. Naukovij Svit, Kyiv, 3: 132-136. (In Ukrainian)

Tur, L. P., L. Y. Rusina. 2001b. Photophobical termites in Kherson region. Structure and Functional Role of Animals Settlement in Natural and Transformed Ecosystems: Theses of the I International Scientific Conference, Dniropetrovsk, 106-107. (In Russian)

Vasiliev, V. P. 1987. Pests of agricultural crops and forest plantations. Harmful Nematodes, Mollusks and Arthropods, 1: 440. (In Russian)

Verkerk, R. H. J. 1998. Termites and Building: assessing the problem from a non-commercial viewpoint. Proceedings of the 1998. Annual Convention of the British Wood Preservation and Damp-Proofing Association, London, BWPDA. 1-8.

Verkerk, R., A. F. Bravery. 2001. The UK termite eradication programme: Justification and implementation. Sociobiology, 37: 351-360.

Vidgalm, I. M. 1886. About Hessian fly and other harmful insects or Bessarabia. Odessa [b.i], 1-107. (In Russian)

What are termites and how to fight them. 2013. 03.03.2013. http://goo.gl/xYQZhh (In Russian)

Yakobson G. G. 1904. Termites of Russia. Works of Entomology office of Scientific Committee of Main Board of Land Use and Agriculture, 4 (8): 3-54. (In Russian)

Zagorodniuk, I. 2012. Alien species in the synanthropic locations of Luhansk region. Dynamics of Biodiversity (Collection of scientific articles). Taras Shevchenko Luhansk National University Press, Luhansk, 86-92. (In Ukrainian)

Zhuzhikov, D. P. 1979. Termites in the USSR. Publishing outfit of Moscow University, 1-225. http://www. activestudy.info/termity/ (In Russian)

Zhuzhikov, D. P., M. V. Korovkina. 1968. The questions of termites food on the Black Sea coast of the USSR. Termites and Fight Against Them, 137-141. (In Russian) 